\title{
Quality of guava fruits bagged with different materials in an organic system
}

\author{
Sebastião Elviro de Araújo Neto*(D), Cleb Rocha(D), Josianny Feitosa de Farias (D), \\ Shirlei Cristina Cerqueira Minosso(i), Regina Lúcia Félix Ferreira(b) \\ Federal University of Acre, Rio Branco, Brazil \\ *Corresponding author, e-mail: selviro2000@yahoo.com.br
}

\begin{abstract}
This study aimed to evaluate the interference of bagging materials on the incidence of insect larvae and the physical and chemical quality of the guava cv. Paluma in an organic system. The experimental design was in randomized blocks with seven treatments and four replications of 25 fruits each. The bagging materials (treatments) were: nonwoven fabric (TNT), transparent plastic bag, white plastic bag, parchment paper, kraft paper, and non-bagged fruits (control). The titratable acidity (TA), ascorbic acid, soluble solids (SS), SS/TA ratio, fresh mass, fruit diameter, fruit length, appearance, and fruit fly incidence were evaluated. Fruit bagging increased the fresh fruit mass, except the tulle bag, which did not change fruit diameter but increased fruit length. There was a high incidence of fruit flies in the non-bagged fruits (100\%) and in those with tulle bags (56.53\%), reduced to $2.15 \%$ when using parchment paper, and reaching the absence of bored fruits when using nonwoven fabric, transparent plastic, and white plastic bags, materials that provided the highest percentages of marketable fruits. All bagging materials did not change the total titratable acidity content and the SS/TA ratio; however, all of them reduced the content of total soluble solids, except the tulle bag. Fruit bagging with nonwoven fabric and parchment paper increased the content of ascorbic acid. Fruit bagging with parchment paper, plastic bag, and nonwoven fabric are efficient in the organic production of guavas for preventing the infection by insect larvae and maintaining the physical and chemical quality of the fruit.
\end{abstract}

Keywords: Psidium guajava, phyłosanitary quality, fruit bagging

\section{Introduction}

Guava (Psidium guajava L.) is the most important species of the genus Psidium, growing and developing in tropical and subtropical climatic conditions, producing fruits of high commercial value that are rich in minerals and vitamin $\mathrm{C}$, and containing several medicinal ingredients (Oliveira et al., 2019).

Guava is among the most attacked fruit species by insects and pathogens, which leads to the use of pesticides for phytosanitary treatments, especially to control fruit flies in conventional cultivation systems, whose main problem is fruit contamination. In organic fruit farming, in spite of the effect of the extracts of toxic plants and the Bordeaux and lime-sulfur mixtures in reducing fruit fly infestation (Pinheiro, 2006), fruit bagging has been an effective and widely used practice for insect control (Pinheiro, 2006; Nascimento et al., 2011; Moura et al., 2011), also being able to avoid mechanical injuries and losses by diseases (Teixeira et al.,
2011; Fernandes et al., 2019).

Besides insect control, bagging also influences the post-harvest and quality of the fruit, and may even increase weight, modify fruit color (Tokairin et al., 2014), as well as increase size, humidity, and the contents of vitamin C (Hossain et al., 2018) and soluble solids (Edirimanna et al., 2015; Meena et al., 2016).

For guava, the highest efficiency occurs when bagging is performed in fruits with diameter ranging from 2.0 to $3.0 \mathrm{~cm}$ (Azevedo et al., 2016).

In spite of the low cost with agrochemicals, fruit bagging in guava is still an expensive agricultural practice, increasing the total cost by $8.6 \%$. For dealing individually with each fruit (Tokairin et al., 2014), it is necessary to evaluate materials of low cost, weatherresistant, harmless to the fruits, and of easy management. The most common materials are kraft paper bags, newsprint, parchment paper, micro-perforated plastic, 
and nonwoven fabric (Teixeira et al., 201 1; Edirimanna et al., 2015; Meena et al., 2016; Hossain et al., 2018).

The materials should not allow the contact of the ovipositor apparatus of the fly with the guava epicarp in order to avoid the hatching and penetration of the organisms in the fruit, causing damage to the pulp, However, besides presenting low cost and easiness of management of the material, there may occur alterations in fruit quality.

Therefore, this work aimed to evaluate the interference of the bagging material on the incidence of insect larvae and the physical and chemical quality of the guava cv. Paluma cultivated in an organic production system.

\section{Material and Methods}

The experiment was performed in an organic orchard of the guava cultivar Paluma with six years of age, in a $6 \mathrm{~m} \times 5 \mathrm{~m}$ spacing, in the Seridó Ecological Site, in the period from March to September 2018, located on Highway AC-10, km 4, Rio Branco, AC, at latitude $09^{\circ}$ 53' 10,6" S and longitude 67\% 49' 08.6" W, with a mean elevation of $170 \mathrm{~m}$, tropical climate (hot and humid), and mean temperature varying from 25 to $34^{\circ} \mathrm{C}$.

The experimental design employed was in randomized blocks, with seven treatments, four replications, and 25 fruits per plot. The treatments were formed by the fruit bagging materials: nonwoven fabric (TNT), transparent plastic bag (15 x $25 \mathrm{~cm})$, white plastic bag $(15 \times 25 \mathrm{~cm})$, parchment paper $(7 \times 20 \mathrm{~cm})$, tulle fabric $(12 \times 25 \mathrm{~cm})$, kraft paper $(6 \times 20 \mathrm{~cm})$, and unbagged fruit (control).

The nonwoven and tulle fabric bags were manually sewn in a domestic sewing machine, with overlock stitches in the extremities, except in the aperture.

Plastic and nonwoven bags are efficient and resistant to rainfall and winds; tulle fabric bags allow gas exchange and do not cause alterations in fruit quality; however, parchment paper and kraft paper bags are the most used due to their low cost (Teixeira et al., 2011 ; Edirimanna et al., 2015; Meena et al., 2016; Hossain et al., 2018)

At the beginning of March, the pruning of all guava plants used in the experiment was performed to allow the sprout induction of new branches, which formed new fruits. After pruning, the Bordeaux mixture at a $1 \%$ concentration was applied to prevent the attack by pathogens.

A mixture of neem oil (1\%) with a lime-sulfur mixture (4\%) was applied prior to fruit bagging to prevent plagues and diseases.

The fruits were bagged in the hard-green stage, before any attack by plagues and diseases, using a cotton string for fixing the material, and performing fruit thinning before bagging, whenever necessary.

The fertilization of the crop was performed by weeding the spontaneous plants every 60 days using a backpack brush cutter. The plants were irrigated through a micro-sprinkler irrigation system, in the months from May to September, comprising the drought period.

Weekly surveys were performed in the orchard for the replacement of any bagging material in case it was missing or damaged by the action of insects, wind, or rainfall.

The physical and chemical quality of the fruits was evaluated by the external appearance, fruit length, diameter, fresh mass, percentage of damaged fruits (unfit for commercialization), presence of borer, soluble solids, ascorbic acid, pH, and titratable acidity, determined according to the methodology described by the Adolf Lutz Institute (IAL, 2009).

Fruit harvest was performed every two days when all fruits presented a yellow peel, an indicator used for quality uniformity. The fruits were separated and identified, placed in boxes to avoid mechanical damage, and transported to the laboratory of the Technology Unit of the Federal University of Acre to perform the analyses.

The visual appearance evaluation of the fruits was performed by identifying severe injuries (deep injuries, rotting, physiological alterations) and slight injuries (superficial damage, healing injury, misshapen navel, deformation, stains, and wrinkling), applying a scale with values from 1 to 5 , in which a grade from 1 to 3 corresponded to marketable fruits, and fruits grading from 4 to 5 were discarded for containing deep injuries, rotting, and infection by insect larvae. This criterion was created by the project team since there are no classification standards for grading organic guava. Araújo Neto \& Ferreira (2019) suggest that the classification of the organic component should consider the content of nutrients and that the external attributes, such as shape and small healed lesions, should be accepted by the consumers and not imposed by the conventional market.

The evaluation of fruit diameter and length was performed by measuring the perpendicular and equatorial axes of the fruit, using a digital pachymeter in $\mathrm{mm}$, with a precision of $0.01 \mathrm{~mm}$.

Mass measurement was performed in individual fruits using an electronic balance with a precision of $0.01 \mathrm{~g}$.

The fruits were cut into four equal parts to verify the presence or not of the fruit fly borer, a methodology 
proposed by Tokairin (2012).

For the performing of the chemical analyses, the guava fruits were crushed and passed through a finemesh sieve in order to separate the pulp from the seeds to assess the content of soluble solids (SS), expressed in ${ }^{\circ}$ Brix, the titratable acidity (TA), expressed in percentage of citric acid, the content of ascorbic acid, pH, and the SS/TA ratio.

The content of soluble solids was determined through the direct reading of the fruit juice in a portable 'ATAGO' digital refractometer, previously calibrated with distilled water, with a reading in the range from 0 to 32 , expressed in Brix (IAL, 2009), after the homogenization of the pulp. The readings of the juice were performed in triplicate.

The titratable acidity (\%) was obtained by weighing $5 \mathrm{~g}$ of the crushed samples in an Erlenmeyer flask, extracted by adding $50 \mathrm{~mL}$ of distilled water and 4 drops of phenolphthalein at $1 \%$ for later titration with sodium hydroxide $(0.1 \mathrm{~N})$ until reaching a faint pink color (IAL, 2009).

The content of ascorbic acid $\left(\mathrm{mg}^{1} 100 \mathrm{~g}^{-1}\right)$ was determined by weighing $5 \mathrm{~g}$ of the crushed samples in an Erlenmeyer flask, adding $20 \mathrm{~mL}$ of sulfuric acid at $20 \%$, $1 \mathrm{~mL}$ of potassium iodide at $10 \%$, and $1 \mathrm{~mL}$ of starch at $1 \%$, titrated with potassium iodate $(0.1 \mathrm{M})$ until reaching a blue-violet color (IAL, 2009).

The SS/TA ratio is a sweetness indicator in fruits. The higher is its value, the more sugar, and less acidity a fruit presents. From the reading of the contents of soluble solids and acidity, the SS/TA ratio was estimated by the mathematical ratio between these two variables.

The data obtained were subjected to analysis of variance, and the means were compared by Tukey's test at a $5 \%$ level of probability with the aid of the SISVAR statistical software, along with Friedman's test for the variables of fruits without borer and marketable fruits since these presented no sampling error in some treatments, being performed with the aid of the ASSISTAT statistical software.

\section{Results and Discussion}

The bagging material altered the contents of SS and ascorbic acid, as well as the physical variables (mass, diameter, length, appearance, and fruits without borer), but did not change the content of TA and the SS/TA ratio (Tables 1 and 2).

This physical alteration in bagged fruits was also observed by Tokairin et al. (2014), Fernandes et al. (2019), and Hossain et al. (2018), increasing weight and changing coloration, besides increasing the content of
$\mathrm{Ca}$, anticipating ripening, and reducing the incidence of fungi and injuries by insects, thus reducing the applications and residue levels of agrochemicals.

Table 1. Mean values of the physical variables of guava fruits bagged with different materials.

\begin{tabular}{|c|c|c|c|}
\hline \multirow{2}{*}{ Treatments } & \multicolumn{3}{|c|}{ Variables } \\
\hline & Mass (g) & Diameter (n & Length (mm) \\
\hline Non-bagged fruit & $116.60 a$ & $59.80 a$ & $62.40 a$ \\
\hline Tulle fabric bag & $138.83 a$ & $62.97 a$ & $67.90 \mathrm{~b}$ \\
\hline White plastic bag & $147.98 b$ & $63.76 a$ & $69.07 b$ \\
\hline Transparente plastic & $153.18 b$ & $62.98 a$ & $69.30 \mathrm{~b}$ \\
\hline Kraft paper & $154.25 b$ & $63.35 a$ & $69.62 \mathrm{~b}$ \\
\hline Parchment paper & $164.41 \mathrm{C}$ & $64.48 \mathrm{~b}$ & $70.38 c$ \\
\hline Nonwoven fabric & $189.00 c$ & $68.85 \mathrm{~b}$ & $75.95 c$ \\
\hline Mean & 152.03 & 63.73 & 69.23 \\
\hline CV (\%) & 7.50 & 3.16 & 4.07 \\
\hline
\end{tabular}

All tested materials, except the tulle fabric bag, provided a higher fruit mass (Table 1), although the $100 \%$ incidence of fruit flies in non-bagged fruits and $56.53 \%$ in fruits bagged with tulle fabric have been responsible for the reduction in fruit mass and marketable fruits (Table 2). Guava fruit bagging increases the length, diameter, and mass of the fruit, caused by their metabolic alteration (Tokairin et al., 2014; Azevedo et al., 2016), a behavior that has also been observed in other fruits, such as in the 'Royal Gala', 'Fuji Suprema', 'Catarina', and M-11/00m apples (Santos et al., 2015). For apples, the white nonwoven fabric bags provided fruits with higher mass and diameter.

Fruits with higher mass were observed when using parchment paper and nonwoven fabric bags (Table 1), the same behavior observed by Azevedo et al. (2016) in guava fruits bagged with newsprint, attributing this to the higher accumulation of water in the tissues as a consequence of the lower exposure to solar radiation and the action of wind on the fruits.

Physical changes in bagged guava fruits occur due to the creation of a microclimate around the fruit (Hossain et al., 2018).

Nonwoven fabric and parchment paper bags possibly present the capacity of filtering the sunlight strips that interfere with the metabolic action of the fruits, as well as in the formation, in their interior, of an ideal microclimate that favors a better fruit development, providing fruits with higher mass, diameter, and height (Azevedo et al., 2016).

The materials used to manufacture the bags reduced the percentage of injured fruits (Table 2), except the tulle fabric, which produced $56.53 \%$ of fruits with the borer. The white and transparent plastics and the nonwoven fabric bags avoided injuries in $100 \%$ of the 
fruits.

The high borer infestation in the fruits bagged with tulle fabric must have occurred because the material used to manufacture the bags presented an aperture diameter of $1.5 \mathrm{~mm}$, allowing the fruit flies to lay their eggs directly on the fruits through the apertures in the bags. Although this material allows the fruits to perform a high interaction with the external environment, as well as gas exchanges, it did not present a positive effect for fruit borer control.

Bags that allow oviposition, either for the characteristic of the fabric or for physical injuries caused by weathering, such as in the paper bags, can increase the incidence of fruits injured by insects (Azevedo et al., 2016).

Fruit bagging, therefore, besides protecting fruits against the attack by insects, allows the harvest of guava fruits with better quality and with better market prices (Fisher et al., 2011).

Table 2. Percentage of guava fruits without fruit borer and marketable fruits according to the treatments provided.

\begin{tabular}{lcc}
\hline \multirow{2}{*}{ Treatments } & \multicolumn{2}{c}{ Fruits (\%) } \\
\cline { 2 - 3 } & Without borer & Marketable \\
\hline Non-bagged fruits & $0.00 \mathrm{a}$ & $0.00 \mathrm{a}$ \\
Tulle fabric & $43.47 \mathrm{~b}$ & $43.50 \mathrm{~b}$ \\
White plastic bag & $100.00 \mathrm{C}$ & $98.00 \mathrm{c}$ \\
Transparent plastic bag & $100.00 \mathrm{C}$ & $95.75 \mathrm{C}$ \\
Kraft paper & $92.86 \mathrm{C}$ & $95.75 \mathrm{C}$ \\
Parchment paper & $97.85 \mathrm{C}$ & $95.50 \mathrm{C}$ \\
Nonwoven fabric & $100.00 \mathrm{C}$ & $97.75 \mathrm{C}$ \\
\hline CV (\%) & - & 7.46 \\
\hline Means followed by the same letter do not differ statistically from each other by Friedman's test \\
at a 5\% level of probability.
\end{tabular}

Table 3. Mean values of the chemical variables of guava fruits bagged with different materials.

\begin{tabular}{lcccc}
\hline \multirow{2}{*}{\multicolumn{1}{c}{ Treatments }} & \multicolumn{4}{c}{ Variables } \\
\cline { 2 - 5 } & SS ( ${ }^{\circ}$ Brix) & $\begin{array}{c}\text { TA } \\
\text { (g/100g) }\end{array}$ & $\begin{array}{c}\text { SS/TA } \\
\text { Ratio }\end{array}$ & $\begin{array}{c}\text { Asc. acid. } \\
\text { (mg/100g) }\end{array}$ \\
\hline Non-bagged fruits & $8.34 \mathrm{a}$ & $0.70 \mathrm{a}$ & $11.9 \mathrm{a}$ & $33.36 \mathrm{~b}$ \\
Tulle fabric & $7.73 \mathrm{a}$ & $0.61 \mathrm{a}$ & $12.7 \mathrm{a}$ & $32.81 \mathrm{~b}$ \\
White plastic bag & $7.89 \mathrm{~b}$ & $0.63 \mathrm{a}$ & $12.5 \mathrm{a}$ & $27.11 \mathrm{~b}$ \\
Transparent plastic bag & $7.27 \mathrm{c}$ & $0.68 \mathrm{a}$ & $10.7 \mathrm{a}$ & $24.04 \mathrm{~b}$ \\
Kraft paper & $8.23 \mathrm{~d}$ & $0.59 \mathrm{a}$ & $13.9 \mathrm{a}$ & $28.69 \mathrm{~b}$ \\
Parchment paper & $7.07 \mathrm{e}$ & $0.71 \mathrm{a}$ & $9.96 \mathrm{a}$ & $18.92 \mathrm{a}$ \\
Nonwoven fabric & $7.00 f$ & $0.70 \mathrm{a}$ & $10.0 \mathrm{a}$ & $21.21 \mathrm{a}$ \\
\hline Mean & 7.65 & 0.66 & 11.65 & 26.59 \\
CV (\%) & 4.47 & 18.54 & 17.18 & 17.68 \\
\hline Means followed by the same letter do not differ statistically from each other by Tukey's test at a \\
$5 \%$ level of probability.
\end{tabular}

The mean of the soluble solids content was 7.65 ${ }^{\circ}$ Brix, with amplitude from 7.0 to 8.34 , ${ }^{\circ}$ Brix. For bagged fruits with a diameter below $4.0 \mathrm{~cm}$, Azevedo et al. (2016) also observed no difference between SS values in guava fruits, varying from 8.07 to $10.05 \%$.

For apples, Feng et al. (2014) observed the reduction of some sugars in bagged fruits, reducing the ss value.

The titratable acidity of the fruits was not influenced by the type of material used for bagging, with a mean of 0.66 and values ranging from 0.59 to 0.71 . Although the metabolism of the fruits was altered with the bagging, and a reduction of malic and ascorbic acids may have occurred, as well as in other acids, such as citric, quinic, and shikimic acids, which had their concentrations increased, there may have occurred a balancing in the total value of acids (Feng et al., 2014).

The contents of ascorbic acid found in the present study varied between 18.92 and 33.36 mg.100 g-1 (Table $3)$, with the highest values being verified for non-bagged fruits and fruits bagged with tulle fabric, with values of 33.36 and $32.81 \mathrm{mg} .100 \mathrm{~g}^{-1}$, respectively, although not differing from the treatments using kraft paper, white plastic, and transparent plastic bags, with these being statistically superior to the fruits bagged with nonwoven fabric and parchment paper, which presented the lowest values. The reduction in ascorbic acid was also observed by Feng et al. (2014) in bagged apples.

Guava bagging reduces fruit acidity, as verified in a study performed by Pinheiro (2006) with the guava variety Red Pirassununga in Viçosa, MG, in which early fruits (from 1.0 to $1.5 \mathrm{~cm}$ ) bagged with white plastic presented a higher content of ascorbic acid than fruits bagged in an advanced growth stage (from 2.0 to 2.5 $\mathrm{cm})$.

The increase in the content of vitamin $C$ in bagged guava fruits was also observed by Meena et al. (2016) and Hossain et al. (2018). The decrease in the content of vitamin $\mathrm{C}$ is attributed to the oxidation of ascorbic and dehydro-ascorbic acids by the activity of the ascorbic acid oxidase enzyme (Hossain et al., 2018).

The ratio of soluble solids/titratable acidy did not differ ( $p>0.05)$ with the type of bagging material, with a mean of 11.65 varying from 9.96 to 13.9. Since the TA value did not differ between fruits under different bagging material, and there was a reduction in the content of soluble solids, the quotient of these two units was not significantly altered.

These results are in accordance with Tokairin (2012), who also observed no difference for the SS/TA ratio in red guava fruits (Pedro Sato) bagged with paper (18.7), with nonwoven fabric (16.8), and in non-bagged fruits (16.8). The non-alteration in the acidity content of the fruits contributes to this, such as occurred in this study.

The bagging materials employed resisted to climatic variations throughout the experiment, without 
rupturing, ensuring the integrity of the bag. The treatments with nonwoven fabric and transparent plastic bags showed to be more resistant than the remainder, being also able to be reused (Teixeira et al., 2011).

\section{Conclusions}

The high incidence of bored fruits without bagging (100\%) and using tulle fabric bags (56.53\%) is reduced to $2.15 \%$ when using parchment paper, reaching a production level with no affected fruits when the bagging was performed with nonwoven fabric, transparent plastic, and white plastic bags, materials that provided the highest percentages of marketable fruits.

All bagging materials did not alter the contents of titratable acidity and the SS/TA ratio, although reducing the content of soluble solids, except for the tulle fabric bags.

The bagging with nonwoven fabric and parchment paper increased the content of ascorbic acid.

The bagging with plastic and kraft paper bags provided fruits with higher fresh mass.

\section{Acknowledgments}

To CNPq and CAPES for granting the scholarships to the authors, and for the financial support.

\section{References}

Araújo Neto, S.E., Ferreira, R.L.F. 2019. Agricultura ecológica tropical. Clube de autores, Rio Branco, Brazil. $169 \mathrm{p}$.

Azevedo, F.R., Nere, D.R., Santos, C.A.M. 2016. Efeito do ensacamento sobre a incidência de moscas-das-frutas e na qualidade das goiabas. Instituto Biológico 83: 1-8.

Edirimanna, E., Amarathunga, D., Amarasena, B. Kirinde, T. 2015. Effect of bagging materials and bag colour on fruit weight and quality of guava (Psidium guajava L.). Annals Sri Lanka Department Agriculture 17: 297-302.

Fernandes, M.B., Mizobutsi, E.H., Rodrigues, M.L.M., Ribeiro, R.C.F., Mizobutsi, G.P., Pinho, D.B. 2019. Bagging time of 'Prata-anã' banana regarding anthracnose control. Revista Brasileira de Fruticultura 41: e-066.

Feng, F., Li, M., Ma, F., Cheng, L. 2014. The effects of bagging and debagging on external quality metabolites, and the expression of anthocyanin biosynthetic genes in 'Jonagold' apple (Malus domestica Borkh.). Scientia Horticulturae 165: 123-131.

Fisher, I.H., Almeida, A.M., Arruda, M.C., Bertani, R.M.A., Garcia, M.J.M., Amorim, L. 2011. Danos em pós-colheita de goiabas na Região do Centro-Oeste Paulista. Bragantia 70: 570-576.

Hossain, M., Rahman, M., Rahim, A., Rubel, H.K., Islam, Z. 2018. Effect of pre-harvest fruit bagging on post-harvest quality of guava cv. Swarupkathi. Fundamental and Applied Agriculture 3: 363-371.

IAL. Instituto Adolfo Lutz. 2009. Métodos físico-químicos para análise de alimentos. 4. ed. IAL, São Paulo, Brazil.

Meena, K.R, Maji, S., Kumar, S., Parihar, D., Meena, D. 2016. Effect of bagging on fruit quality of guava. International Journal of Bio-resource and Stress Management 7:330333.

Moura, E.S., Azevedo, F.R., Santos, C.A.M., Nere, D.R., Azevedo, R. 2011. Controle de pragas da goiabeira (Psidium guajava) com ensacamento de frutos. Cadernos de Agroecologia 6: 1-5.

Nascimento, W.M.O., Müller, C.H., Araújo, C.S., Flores, B.C. 2011 . Ensacamento de frutos de abiu visando à proteção contra o ataque da mosca-das-frutas. Revista Brasileira de Fruticultura 33: 48-52.

Oliveira, P.G., Queiróz, M.A., Castro, J.M.C., Ribeiro, J.M., Oliveira, R.S., Silva, M.J.L. 2019. Reaction of Psidium SPP. accessions to different levels of inoculation with Meloidogyne enterolobii. Revista Caatinga 32: 419-428.

Pinheiro, S.S.C. 2006. Qualidade de goiabas ensacadas e manejadas com diferentes produtos fitossanitários, sob manejo orgânico. 91f. (D.Sc. Thesis) - Federal University of Viçosa, Viçosa, Brazil.

Santos, J.P., Hickel, E.R., Argenta, L.C. 2015. Efeito do ensacamento na qualidade de maçãs em diferentes estádios de desenvolvimento. Revista Brasileira de Fruticultura 37: 667-675.

Teixeira, R., Boff, M.I.C., Amarante, C.V.T., Steffens, C.A., Boff, P. 2011. Efeito do ensacamento dos frutos no controle de pragas e doenças e na qualidade e maturação de maçãs 'Fuji Suprema'. Bragantia 70: 688-695.

Tokairin, T.O. 2012. Qualidade físico-química, incidência de doenças pós-colheita e custo de produção de goiabas ensacadas no campo. 68f. (M.Sc. Thesis) - University of São Paulo, São Paulo, Brazil.

Tokairin, T.O., Cappello, F.P., Spósito, M.B. 2014. Custo de produção de goiabas para mesa produzidas com e sem ensacamento: estudo de caso. Revista Brasileira de Fruticultura 36: 542-549.

Conflict of Interest Statement: The authors declare that the research was conducted in the absence of any commercial or financial relationships that could be construed as a potential conflict of interest.

All the contents of this journal, except where otherwise noted, is licensed under a Creative Commons Attribution License attribuition-type BY. 